\title{
Strategi Komunikasi dalam Membangun Kebiasaan Makan Pangan Lokal Percepatan Penganekaragaman dan Konsumsi Pangan di Kabupaten Bengkulu Utara
}

\author{
M. Zulkarnain Y, Subejo dan Slamet Hartono \\ Mahasiswa program S-3 Program Studi Penyuluhan dan Komunikas Pembangunan \\ Sekolah Pascasarjana Universitas Gadjah Mada \\ Email: idjul.ar@gmail.com
}

\begin{abstract}
This study aims to identify the communication strategy on P2KP activities in building society's habits in eating local food. The study was conducted in five districts and seven villages in North Bengkulu. The total number of samples are 280 housewives. The number of samples in each village are determined by quota sampling, and sample in each village is determined by simple random sampling technique. The results showed that stages in communication planning model in $P 2 K P$ activity not so different with community planning at another empowerment that have been done before. Communication strategy conducted through P2KP been considered appropriate and able to convey the messages of diversification and start to change the society's habits in eating local food, especially in the aspect of the approach technique and message. Communication strategy through the media is considered less appropriate in conveying the message of diversification, because of the less affordability of the public to access information through mass media
\end{abstract}

Keywords: communication strategy, food habits, local food

\begin{abstract}
Abstrak
Penelitian ini bertujuan untuk mengidentifikasi strategi komunikasi pada kegiatan P2KP dalam membangun kebiasaan makan pangan lokal masyarakat. Penelitian dilakukan pada lima kecamatan dan tujuh desa di Kabupaten Bengkulu Utara. Jumlah total sampel sebanyak 280 orang ibu rumah tangga dimana jumlah sampel tiap desa ditentukan dengan quota sampling, dan penentuan sampel di tiap desa ditentukan dengan tehnik simple random sampling. Hasil penelitian menunjukkan bahwa model perencanaan komunikasi kegiatan P2KP merupakan model perencanaan yang tahapan-tahapan kegiatannya tidak begitu berbeda dengan tahapan-tahapan model perencanaan komunikasi pada kegiatan pemberdayaan masyarakat yang pernah ada. Strategi komunikasi yang dilakukan melalui kegiatan P2KP sudah dianggap tepat dan mampu menyampaikan pesan-pesan diversifikasi dan mengubah kebiasaan makan pangan lokal masyarakat, khususnya pada aspek pendekatan dan pesan. Hanya saja strategi komunikasi melalui media dianggap kurang tepat dalam menyampaikan pesan diversifikasi karena keterjangkauan masyarakat dalam mengakses informasi melalui media massa juga sangat rendah.
\end{abstract}

Kata Kunci: Strategi komunikasi, kebiasaan makan, pangan lokal 


\section{Pendahuluan}

Komunikasi adalah proses pengalihan pesan yang dilakukan seseorang melalui suatu saluran tertentu kepada orang lain dengan efek tertentu pula. Disebut sebagai proses, karena komunikasi bersifat dinamis,selalu berlangsung dan berubah-ubah (DeVito, 2006). Dalam sebuah proses interaksi komunikasi, sangat tergantung pada keterampilan- keterampilan tertentu untuk membuat pertukaran informasi menjadi efektif. Komunikasi yang memuat berbagai pesan program pembangunan, merupakan hal yang esensial dalam pembangunan itu sendiri karena memiliki peranan penting dalam memberdayakan dan mengubah masyarakat, khususnya untuk menerima ataupun menerapkan suatu inovasi menuju masyarakat yang lebih baik. Pesanpesan pembangunan yang disampaikan dengan tepat, jelas, dan terarah akan memudahkan pemahaman sasaran untuk mengubah sikap dan perilaku ke arah yang diharapkan (Versoza dan Gracia, 2009).

Salah satu program pemerintah dalam bidang konsumsi pangan adalah meningkatkan diversifikasi konsumsi pangan, yaitu proses pemilihan pangan yang ditujukan untuk mengurangi ketergantungan konsumsi yang tinggi pada beras dengan sumber pangan lokal dengan memperhatikan aspek beragam, bergizi seimbang dan aman.

Menurut Undang-undang No. 18/2012, pangan lokal didefinisikan sebagai makanan yang dikonsumsi oleh masyarakat setempat sesuai dengan potensi dan kearifan lokal. Sedangkan menurut Malik (2014), pangan lokal yang juga disebut pangan tradisional didefinisikan sebagai produk pangan yang telah lama diproduksi, berkembang, dan dikonsumsi di suatu daerah atau sekelompok masyarakat lokal tertentu. Produk tersebut umunya diolah dari bahan baku lokal menggunakan teknologi lokal.

Selanjutnya disebutkan Malik, bahwa pangan lokal memiliki fungsi ekonomi, sosial, dan budaya. Pangan lokal bernilai penting bagi kehidupan ekonomi keluarga. Secara budaya, proses pengadaan pangan lokal tersebut berdasarkan pengetahuan lokal, dan biasanya dikembangkan dengan preferensi konsumen lokal pula. Secara sosial, pangan lokal menunjukkan identitas dan jati diri masyarakat. Pada masyarakat tertentu pangan lokal digunakan dalam pesta perkawinan, pesta adat dan acara keluarga, dan dari sinilah status sosial seseorang dalam masyarakat tercermin. Siapa yang menghidangkan makanan paling beragam memiliki status sosial terpandang. Pangan lokal tentunya memiliki peran strategis dalam pembangunan ketahanan pangan.

Keberhasilan program-program diversifikasi dalam merubah kebiasaan makan masyarakat akan sangat tergantung dari bagaimana mengkomunikasikan program-program tersebut dengan strategi komunikasi yang tepat. Strategi komunikasi dapat berperan untuk mengubah pandangan masyarakat yang tadinya negatif menjadi positif terhadap pangan lokal, sehingga pesan yang sudah dirancang dan disampaikan dengan jelas dan terarah akan memudahkan pemahaman masyarakat untuk mengubah sikap dan perilaku kearah yang diharapkan.

Strategi komunikasi pada hakekatnya adalah perencanaan (planning) dan manajemen (management) untuk mencapai satu tujuan. Untuk mencapai tujuan tersebut, strategi tidak hanya berfungsi sebagai peta jalan yang menunjukkan arah saja, melainkan juga harus menunjukkan bagaimana taktik operasionalnya. Strategi komunikasi merupakan paduan dari perencanaan komunikasi dan manajemen komunikasi untuk mencapai suatu tujuan (Effendy, 2003)

Program Percepatan Penganekaragaman Konsumsi Pangan (P2KP) yang dilakukan oleh Badan Ketahanan Pangan (BKP) Provinsi Bengkulu merupakan salah satu usaha untuk mengubah kebiasaan makan masyarakat yang sudah sangat terbiasa dengan beras sebagai pangan karbohidrat utama. Untuk mengurangi ketergantungan yang tinggi pada beras sebagai sumber karbohidrat maka perlu mengganti beras dengan sumber pangan lokal sebagai usaha melakukan diversifikasi. Husodo dan Muchtadi (2004) mengemukakan bahwa substitusi 10 
$\%$ beras dengan bahan pangan non beras akan mengurangi kebutuhan beras hingga 3 juta ton, hal ini berarti dapat menjadi jaminan bagi Indonesia untuk tidak perlu mengimpor beras. Untuk mencapai hal tersebut perlu upaya dan pengembangan pangan pokok lokal non beras berbasis umbi-umbian dan tepung dengan tetap memperhatikan sumber daya lokal sesuai potensi daerah.

BKP sebagai lembaga yang menjalankan program tentu mempunyai strategi dalam mengkomunikasikan dan implementasi gerakan P2KP di masyarakat. Strategi komunikasi yang direncanakan dapat menyampaikan pesan-pesan diversifikasi pangan lokal yang sudah dirancang dapat disampaikan dengan jelas sehingga memudahkan masyarakat untuk mengubah sikap dan perilaku ke arah yang diinginkan, karena pada dasarnya trategi komunikasi adalah manajement perencanaan untuk mencapai suatu tujuan. Fungsi komunikasi pada konteks ini dianggap sebagai mekanisme untuk mendapatkan dukungan dan partisipasi masyarakat dalam pelaksanaan rencana pembangunan (Rogers, 2003). Menurut Nasution (1988), dalam kaitannya dengan program pembangunan komunikasi memunculkan berbagai macam definisi, dan topik yang berkaitan dengan disiplin ilmu lainnya. Meskipun demikian, esensinya adalah memperbincangkan hal yang sama, yakni bagaimana proses komunikasi dapat berperan maksimal dalam pelaksanaan pembangunan. Strategi komunikasi merupakan kombinasi dari pendekatan komunikasi yang dilakukan, pesan yang disampaikan, dan juga penggunaan media atau saluran yang sangat dipengaruhi oleh karakteristik sasaran dan juga tujuan yang akan dicapai (Middleton dan Lin, 1975).

Penelitian ini bertujuan untuk mengidentifikasi strategi komunikasi pada kegiatan P2KP dalam membangun kebiasaan makan pangan lokal masyarakat di Kabupaten Bengkulu Utara.

\section{Metode Penelitian}

Penelitian ini dilakukan pada tujuh desa di lima kecamatan di Kabupaten Bengkulu Utara yang menjadi penerima manfaat kegiatan P2KP, yaitu Desa Pasar Tebat, Desa Lubuk Semantung, Desa Pasar Lais, Desa Sidodadi, Desa Tanah Tinggi, Desa Tebing kaning, dan Desa Sidomukti. Sampel dalam penelitian ini adalah ibu rumah tangga karena dalam struktur masyarakat secara umum peran ibu rumah tangga cukup besar dalam penyediaan pangan di rumah. Selain itu, kegiatan P2KP juga didisain dan dirancang sebagai kegiatan untuk wanita pedesaan yang tergabung di dalam kelompok tani sehingga informasi yang dikumpulkan diharapkan akan lebih valid. Data diperoleh melalui wawancara melalui focus group discussion, observasi, serta pengumpulan data pendukung dengan menggunakan kuesioner.

Untuk mendapatkan sampel yang dapat menggambarkan dan mewakili populasi, maka sampel ditentukan dengan menggunakan tehnik Quota Sampling, dimana dari setiap desa ditentukan sebanyak 40 rumah tangga yang dapat mewakili untuk pengumpulan data yang diinginkan. Sehingga jumlah total sampel dalam penelitian ini adalah 280 rumah tangga. Penentuan sampel dari tiap desa dilakukan dengan menggunakan metode simple random sampling.

Strategi komunikasi yang dikaji adalah strategi komunikasi yang dilakukan pada pelaksanaan program P2KP dalam membangun kebiasaan makan pangan lokal. Disain strategi yang dibuat dan diimplementasikan dalam pelaksanaan program akan dianalisis secara kualitatif Sedangkan untuk strategi komunikasi yang dinilai oleh masyarakat, diukur secara kuantitatif berdasarkan persepsi terhadap pendekatan, pesan, dan media yang digunakan. Diukur dengan menggunakan skala linkert dan disajikan dalam bentuk tabel dan uraian verbal.

\section{Hasil dan Pembahasan \\ Karakteristik Ibu Rumah Tangga}

Informasi tentang karakteristik akan memberikan gambaran mengenai kondisi nyata untuk dapat dihubungankan dengan bagaimana 
rumah tangga berperilaku dalam membangun kebiasaan makan rumah tangga. Karakteristik ibu rumah tangga disajikan Tabel 1.

Rata-rata umur ibu rumah tangga masih berada dalam kategori produktif untuk melakukan aktifitas ekonomis maupun sosial. Dengan usia produktif, mereka dapat melakukan aktivitas ekonomi dengan baik, sehingga dapat memenuhi semua kebutuhan khususnya menyediakan konsumsi keluarga. Sedangkan aktivitas sosial dengan melakukan kontak dengan orang-orang disekitar akan memberikan banyak pengalaman dan meningkatkan modal sosial di tengah masyarakat.

Dari sudut sosial ekonomi, tingkat pendidikan ibu rumah tangga merupakan salah satu aspek yang dapat digunakan untuk mengukur tingkat kesejahteraan suatu rumah tangga. Tingkat pendidikan yang lebih tinggi akan memudahkan seseorang untuk menyerap informasi dan mengimplementasikan dalam perilaku dan gaya hidup sehari-hari. Rata-rata pendidikan ibu rumah tangga adalah 6.04 tahun atau setara SD dengan pendidikan tertinggi selama 14 tahun (S1) dan terendah 3.6 tahun (kelas 3 SD).

Pendidikan dalam rumah tangga akan mempengaruhi pola pengambilan keputusan, dimana dengan pendidikan yang lebih baik memungkinkan suami dan istri mempunyai pemahaman dan perilaku yang baik dalam pengelolaan rumah tangga, termasuk dengan pilihan-pilihan dalam pemenuhan konsumsi pangan. Tingkat pendidikan formal seorang ibu seringkali berhubungan positif dengan peningkatan pola konsumsi makanan rumah tangga.

Pendapatan merupakan jumlah uang yang diterima oleh seseorang atau lebih anggota keluarga yang berkaitan erat dengan jenis pekerjaan yang dilakukan. Rata-rata pendapatan ibu rumah tangga sebesar Rp 1.440 .860 dengan total pendapatan rumah tangga keseluruhan sebesar Rp 4.389.190. Pendapatan akan mempengaruhi akses rumah tangga terhadap pangan, dengan pendapatan yang tinggi akses rumah tangga menjangkau pangan juga akan lebih baik. Kesejahteraan rumah tangga tidak hanya bergantung pada penghasilan yang diperoleh, tetapi juga ditentukan oleh siapa yang mencari nafkah dan mengontrol pengeluaran rumah tangga.

Dibandingkan dengan suami, istri lebih berperan dalam mengalokasikan uang untuk belanja makanan rumah tangganya. Meningkatnya penghasilan rumah tangga yang berasal dari ibu bekerja juga akan memperbaiki konsumsi makanan seluruh anggota rumah tangga (Khomsan, 2004).

Jumlah anggota rumah tangga akan menentukan pilihan konsumsi dan juga menentukan banyak sedikitnya jumlah pangan yang akan dikonsumsi. Rata-rata jumlah anggota rumah tangga sebanyak empat orang. Jumlah anggota rumah tangga yang semakin banyak, akan semakin mengalami kecenderungan menurunnya rata-rata asupan energi dan protein per kapita per hari.

Tabel 1. Karakteristik Ibu Rumah Tangga

\begin{tabular}{|l|l|l|l|l|l|}
\hline No & Karakteristik & Rata-rata & Minimum & Maksimum & $\mathrm{Sd}$ \\
\hline 1 & Umur (th) & 35.32 & 24 & 49 & 5.11 \\
\hline 2 & Lama Pendidikan (th) & 6.04 & 3.6 & 14 & 2.45 \\
\hline 3 & $\begin{array}{l}\text { Pendapatan Rumah Tangga } \\
\text { (Rp/bln) }\end{array}$ & 4.389 .190 & 3.090 .000 & 11.315 .000 & 2.121 .424 \\
\hline 4 & $\begin{array}{l}\text { Jumlah anggota keluarga } \\
\text { (orang) }\end{array}$ & 4 & 2 & 6 & 1.2 \\
\hline
\end{tabular}

Sumber: Analisa data Primer $2016(\mathrm{~N}=280)$ 


\section{Kontak dengan Sumber Informasi}

Sumber informasi bagi masyarakat didapatkan melalui media massa dan sumber informasi interpersonal. Sumber informasi dapat memotivasi dan menggerakan masyarakat untuk lebih terbuka, inovatif dan mampu berpartisipasi dalam pembangunan. Agar partisipasi khalayak menjadi lebih bermakna, sumber informasi apapun akan dituntut untuk mampu memberikan informasi dan pengetahuan-pengetahuan baru kepada masyarakat.

Kemudahan mengakses dan memanfaatkan media massa sebagai sumber informasi yang tersedia merupakan hal yang sangat mendasar, karena saat ini media massa dapat dengan mudah diakses oleh masyarakat dalam situasi apapun. Media massa yang diakses oleh ibu rumah tangga adalah televisi, radio, Koran, tabloid, dan leafleat/poster.

Karakteristik yang melekat pada televisi sebagai media yang mampu menyatukan antara fungsi audio dan visual sehingga dapat memperjelas dan mendekatkan dunia yang jauh tanpa perlu menyediakan waktu dan biaya khusus (Cangara, 2000), menjadikan media ini merupakan satu-satunya media yang dimiliki oleh seluruh rumah tangga. Keberadaan stasiunstasiun televisi saat ini memberikan kemudahan dan pilihan bagi masyarakat secara leluasa untuk menentukan saluran mana yang mereka senangi. Semua responden mengaku menonton televisi tiap harinya dengan rata-rata jam menonton 2.8 jam per hari. Acara yang paling menarik dan paling sering ditonton adalah hiburan, seperti sinetron, film, acara keagamaan, reality show dan infotainment.
Bila dibandingkan dengan jenis media yang lain, televisi dipandang sebagai media yang selalu memberikan informasi yang selalu menarik dan mudah untuk diikuti. Meskipun demikian, hampir semua responden menyatakan bahwa tidak satupun informasi mengenai diversifikasi pangan lokal pernah mereka dapatkan dari acara di televisi.

Sebanyak $40 \%$ responden menyatakan bahwa dalam satu bulan terakhir mereka menikmati siaran radio. Siaran yang paling sering dinikmati adalah siaran hiburan dengan ratarata frekuensi mendengarkan radio sebanyak 2 hari per minggu dengan lamanya mendengarkan selama 1 jam per harinya.

Kelebihan media cetak yang mampu memberi informasi lebih lengkap, bisa dibawa kemana-mana, terdokumentasi dan mudah dinikmati secara berulang (Cangara, 2000), ternyata tidak dapat menjadikan media jenis ini sebagai media yang paling dinikmati oleh sebagian besar rumah tangga. Hal ini dapat dilihat dari hanya $30 \%$ responden yang secara rutin membaca dan mengikuti perkembangan berita dari koran dalam satu bulan terakhir, sedangkan tabloid, hanya 5\%.

Faktor yang mendukung mereka dapat secara rutin menikmati koran/tabloid adalah karena aktivitas suami mereka berada di kawasan ibukota kabupaten bahkan ibukota provinsi, sehingga untuk mengakses dan membeli koran/ tabloid sangatlah mudah. Sedangkan mereka yang tidak dapat menikmati koran/tabloid disebabkan karena faktor ekonomi sangat membatasi mereka dalam menyediakan fasilitas tersebut di rumah. Pemenuhan kebutuhan dasar

Tabel 2. Media Massa yang Diaksesi oleh Responden

\begin{tabular}{|l|l|l|}
\hline No & Jenis Media & Jumlah(\%) \\
\hline 1. & Televisi & 100.00 \\
2. & Koran & 30.00 \\
3. & Tabloid & 10.00 \\
4. & Radio & 40.00 \\
5. & Leafleat & 60.00 \\
\hline
\end{tabular}

Sumber; Data primer diolah 2016. 
rumah tangga dan keperluan sekolah danggap lebih utama bila dibandingkan untuk membeli koran/tabloid.

Sebanyak $60 \%$ responden responden membaca leaflet. Leaflet dinilai mampu memberikan informasi yang lengkap dan jelas mengenai diversifikasi konsumsi pangan lokal. Leafleat biasa diperoleh dari penyuluh, puskesmas, dan anggota ketua P2KP yang aktif. Apabila ada informasi dari leafleat yang membutuhkan penjelasan lebih detail, biasanya responden akan menanyakan pada orang yang lebih mengerti.

Selain media massa, responden memanfaatkan nara sumber formal dan informal sebagai sumber informasi interpersonal mereka. Alasan utama dari mereka yang memanfaatkan nara sumber formal menilai bahwa sumber formal sebagai pembawa informasi dari inovasi sangat dapat dipercaya sehingga untuk informasi-informasi yang lebih akurat, sumber formal merupakan sumber informasi utama. Nara sumber informasi formal yang pernah memberikan informasi mengenai diversifikasi dan keutamaan pangan lokal adalah penyuluh, ketua PKK/Posyandu, petugas puskesmas, serta dokter/bidan yang ada dan sering mereka datangi.

Selain sumber formal, sumber informal juga sering menjadi rujukan rumah tangga dalam memperoleh informasi. Nara sumber informasi non formal bagi ibu rumah tangga dalam penelitian ini adalah teman, tetangga, kerabat dan keluarga. Mencari informasi dari sumber informal dianggaplebih praktis dan lebihfleksibel dibandingkan dengan sumber formal, karena nara sumber informal lebih mudah dihubungi, waktunya lebih bebas, tempatnya juga lebih fleksibel sehingga tidak mengganggu kegiatan mereka sehari-hari. Selain itu, karakteristik individu yang cenderung homogen membuat responden merasa lebih nyaman untuk bertanya dengan lebih leluasa. Situasi ini dijelaskan oleh Mardikanto (2009) yang mengemukakan bahwa sebagian masyarakat yang masih tradisional akan lebih mempercayai pemimpin non formal, teman dan tetangga sebagai kelompok acuan dan sebagai sumber informasi dalam difusi inovasi.

\section{Model Strategi Komunikasi P2KP}

Apabila digambarkan dalam suatu model perencanaan komunikasi, maka disain kegiatan P2KP dapat digambarkan seperti Gambar 1. Model perencanaan komunikasi kegiatan P2KP merupakan model perencanaan yang tahapannya tidak begitu berbeda dengan tahapan pada model perencanaan komunikasi pemberdayaan masyarakat yang pernah ada, dengan tahapan yang umum seperti: perencanaan, persiapan, pelaksanaan, serta evaluasi dan monitoring.

Tahapan dalam kegiatan P2KP, dimulai berdasarkan data dan analisis yang memang sudah tersedia di Badan Ketahan Pangan, seperti data pola pangan harapan ( $\mathrm{PPH})$ masyarakat, dan data sumberdaya lokal potensial yang mempunyai keunggulan kompetitif dan komparatif yang akan menjadi batasan dalam tahapan-tahapan kegiatan selanjutnya menjadi acuan untuk persiapan, pengembangan pesan, pelaksanaan, monitoring dan evaluasi.

Pelaksanaan kegiatan P2KP sudah memuat komponen strategis dalam komunikasi pembangunan seperti yang dijelaskan dalam a guide on communication planning for community-based development, yaitu:

1. Behavior Change communication (BCC) dimana Kegiatan P2KP menggunakan komunikasi partisipatif untuk membantu menginformasikan dan mendukung rumah tangga, tokoh masyarakat, opinion leader, untuk mengadopsi dan menjaga keberlanjutan perilaku konsumsi pangan lokal.

2. Social mobilization. Kegiatan P2KP mengikutsertakan dan memotivasi masyarakat sipil dengan memberikan pendidikan dan memberikan dukungan pada komunitas masyarakat. Hal ini dapat terlihat pada pengoptimalisasi lahan pekarangan melalui kegiatan Kawasan Rumah Pangan Lestari (KRPL), ada proses transformasi informasi dan teknologi, pemahaman masyarakat terhadapnilainilai sumberdaya lokal, hingga pemberdayaan 


\section{Gambar 1. Model Perencanaan Komunikasi P2KP}

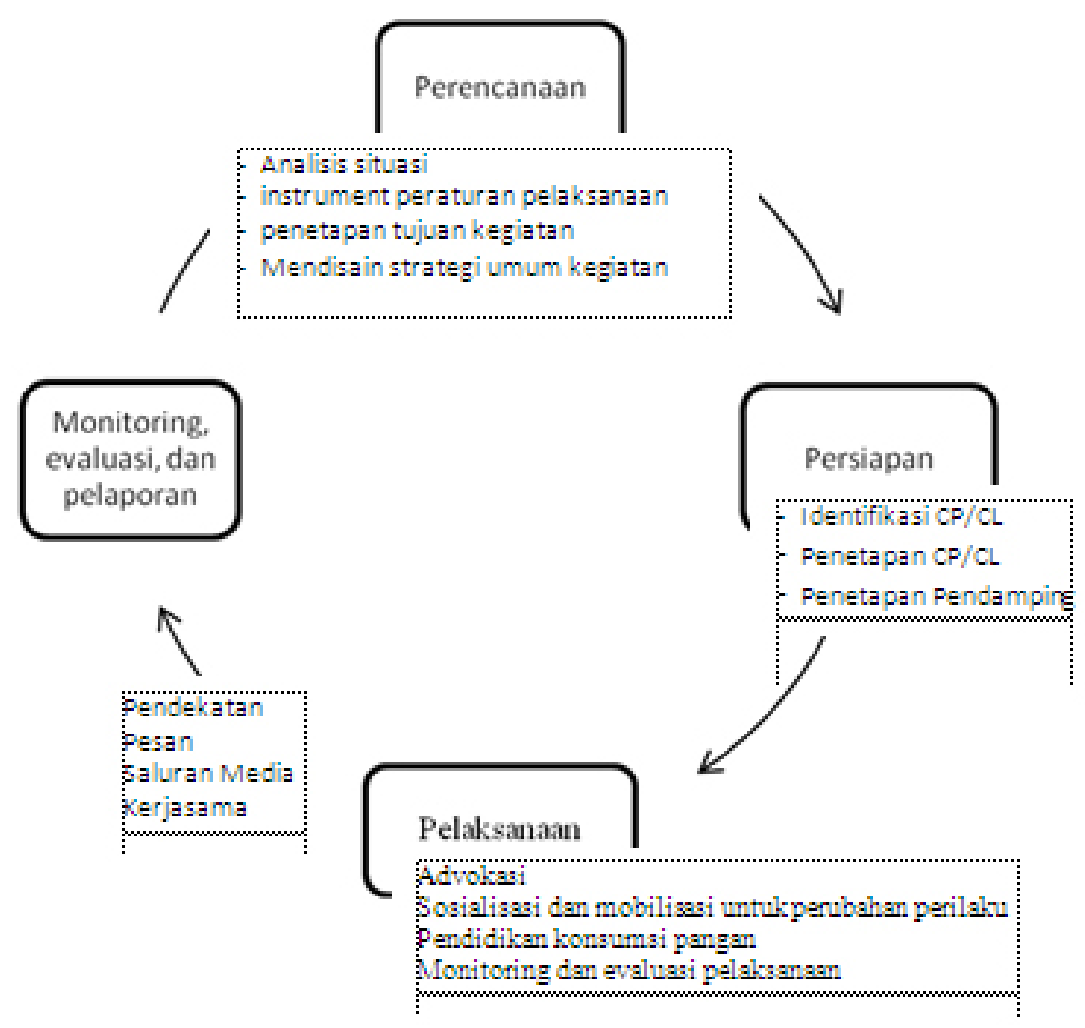

kaum perempuan dalam memanfaatkan sumberdaya lokal untuk menguatkan ketahanan dan kemandirian pangan

3. Advocacy. Membantu membangun mekanisme dan memastikan bahwa perspektif, perhatian dan pendapat dari masyarakat dalam pemenuhan kebutuhan pangan sesuai potensi sumber daya lokal tercermin dalam kebijakan dan pengambilan keputusan. Dengan advokasi, akan terbangun kondisi yang mendukung untuk mencapai tujuan program dan sasaran pembangunan.

Kegiatan P2KP melibatkan partisipasi dalam pemberdayaan masyarakat dengan sumberdaya dan pengetahuan lokal. Paradigma pemberdayaan berjalan ke arah bagaimana masyarakat menentukan sendiri kebutuhannya sesuai dengan need and assessment. Komunikasi pembangunan berperan penting dalam menjembatani kesenjangan antara kondisi masyarakat yang faktual dengan kondisi yang ingin dicapai melalui komunikasi yang partisipatif, dialogis, dan mampu memotivasi masyarakat.

Ada tiga pendekatan utama dan kombinasi antara ketiganya yang saling menguatkan dan digunakan dalam pelaksanaan kegiatan P2KP: 1) Pendekatan perorangan, dilakukan oleh penyuluh/fasilitator berkaitan dengan kegiatan yang dilakukan baik secara langsung ataupun tidak langsung secara perorangan. 2) Pendekatan kelompok dilakukan sehubungan dengan kegiatan optimalisasi pemanfaatan pekarangan melalui konsep KRPL dimana sasaran dari kegiatan adalah kelompok wanita yang diutamakan kelompok wanita tani yang masih aktif. Penyuluh/fasilitator berperan dalam memfasilitasi proses kegiatan dan mengaktifkan jalannya proses belajar melalui pertemuan rutin, pelatihan dan diskusi untuk kelompok. Pertemuan rutin diadakan untuk mengikat seluruh anggota masyarakat yang terlibat dalam aktivitas kelompok dan merupakan kewajiban dan tanggung jawab yang harus dijalani sebagai anggota kelompok. Topik yang dibahas dalam kegiatan pertemuan 
adalah kegiatan yang dilakukan oleh kelompok, baik yang sudah dilakukan ataupun yang akan direncanakan, serta permasalahan-permasalahan yang ada dalam kelompok. Pertemuan kelompok juga dimanfaatkan untuk penyampaian informasi dari BKP3 Kabupaten Bengkulu Utara terkait dengan kebijakan dan informasi rencana bantuan dalam kegiatan KRPL. Pelatihan, sebagai bentuk wahana belajar untuk meningkatkan pengetahuan dan ketrampilan tidak hanya untuk pengembangan lahan pekarangan dengan penerapan teknologi pertanian tertentu, tetapi juga untuk pendidikan konsumsi pangan B2SA untuk hidup sehat, aktif dan produktif dengan membuat demplot kelompok, kebun bibit dan penanganan pasca panen hasil KRPL. Kelompok juga dibekali dengan penguatan manajemen seperti pembukuan, laporan penggunaan dana, dokumentasi dll. Selain itu juga, dilakukan kunjungan kelompok ke kelompok lain yang dianggap sudah baik dalam melakukan pengelolaan optimalisasi pemanfaatan lahan pekarangan dan mampu menularkan pada pada banyak rumah tangga lainnya.

Pertemuan dan pelatihan selalu digunakan sebagai media untuk berdiskusi, bertukarpikiran, memecahkan masalah bersama, proses belajar berdasarkan pengalaman dari setiap anggota sehingga ada pertukaran informasi yang akan bermanfaat untuk mereka. Terkadang, diskusi yang berkaitan dengan kegiatan kelompok dilakukan juga di luar pertemuan resmi, apabila ada permasalahan dapat dibicarakan dalam suasana yang tidak formal, setiap anggota terbuka untuk saling membantu dalam setiap permasalahan yang ada.

Dilihat dari sisi pendampingan, kegiatankegiatan yang sudah disebutkan di atas didukung partisipasi positif dari masyarakat karena keberhasilan penyuluhan/fasilitator untuk tidak menempatkan rumah tangga sebagai target dari kegiatan tetapi menempatkan mereka sebagai penerima manfaat. Hal ini sangat sesuai dengan apa yang diungkap oleh Mardikanto (2009), karena sebagai penerima manfaat akan menempatkan mereka pada posisi yang perlu dilayani atau difasilitasi sebagai rekanan. Sebagai penerima manfaat, mereka akan memiliki posisi tawar untuk menerima atau menolak inovasi yang disampaikan, sehingga tidak perlu memaksakan mereka untuk berpartisipasi, karena dengan kesadaran mereka sendiri mereka terdorong untuk terlibat dan berbuat demi kepentingan bersama. 3) Pendekatan massal dilakukan untuk kegiatan sosialisasi dan promosi P2KP melalui berbagai macam kegiatan kampanye, serta sosialisasi melalui media massa cetak maupun elektronik, promosi pola pangan B2SA, seperti kampanye "one day no rice", pameran diversifikasi pangan, lomba kreatifitas pangan lokal non beras/terigu dan lain sebagainya .

Peran komunikasi pembangunan dalam kegiatan P2KP terlihat sangat luas mulai dari sekedar proses transformasi informasi dan teknologi, pemahaman masyarakat terhadap nilai-nilai sumberdaya lokal, hingga pemberdayaan kaum perempuan dalam memanfaatkan sumberdaya lokal untuk menguatkan ketahanan dan kemandirian pangan. Dalam hal ini, kegiatan P2KP sangat memainkan peranan dalam perubahan terencana melalui proses komunikasi yang partisipatif, dialogis, dan memotivasi masyarakat.

Dengan perencanaan strategi komunikasi yang dilakukan, beberapa dampak positif dari adanya kegiatan P2KP yang dapat dirasakan langsung oleh masyarakat, adalah: 1) Peningkatan keterampilan rumah tangga, dalam melakukan pengelolaan lahan pekarangan untuk menguatkan ketahanan dan kemandirian pangan rumah tangga 2) Peningkatan kemampuan diversifikasi usahatani dengan kegiatan produktif dengan mengedepankan nilai-nilai dan sumberdaya lokal, serta prinsip keberlanjutan. 3) Meningkatkan pemahaman dan memotivasi masyarakat untuk melakukan keragaman konsumsi pangan dengan sumberdaya pangan lokal. 4) Penguatan kelembagaan lokal, khususnya kelompok wanita tani

Namun demikian, gerakan yang dilakukan melalui kegiatan P2KP belum sepenuhnya dapat mengubah kebiasaan makan masyarakat. 
Penyampaian pesan melalui saluran-saluran komunikasi yang kurang tepat akan membuat transfer informasi menjadi tidak berjalan sesuai dengan perencanaan. Sejatinya setiap manusia akan mampu mengenali permasalahan mereka bila memiliki informasi yang memadai, dan untuk memperolehnya dibutuhkan sumberdaya dan akses terhadap sumber informasi.

Pesan diversifikasi haruslah mudah dipahami, dan peka terhadap budaya setempat sehingga akan memudahkan dan meyakinkan sasaran bahwa perilaku yang baru akan memberikan manfaat yang jelas bagi sasaran, karena strategi untuk mengkomunikasikan pesan ini tidak hanya sekedar merupakan usaha untuk mengkonstruksi masyarakat terhadap isu diversifikasi pangan tetapi juga mempertaruhkan sisi psikologis masyarakat untuk mengubah skemata yang sudah terlanjur melekat bahwa "belum makan kalau belum makan nasi".

\section{Persepsi terhadap Strategi Komunikasi}

Keberhasilan program-program
diversifikasi dalam merubah kebiasaan
makan masyarakat akan sangat tergantung dari bagaimana mengkomunikasikan program-program tersebut dengan strategi komunikasi yang tepat. Program-program yang dikomunikasikan dengan efektif dapat mengubah perilaku dan kebiasaan masyarakat. Lembaga pelaksana program memegang peran penting untuk melakukan fungsi pelayanan dan fasilitasi dalam sebuah proses belajar bersama yang partisipatif sehingga dapat menambah pengetahuan, pemahaman sehiingga mampu merubah sikap dan perilaku mereka dalam mengubah kebiasaan makan dari beras ke sumber pangan lain.

Strategi komunikasi dapat berperan untuk mengubah pandangan masyarakat yang tadinya negatif menjadi positif terhadap pangan lokal, sehingga pesan yang sudah dirancang dapat disampaikan dengan jelas dan terarah sehingga memudahkan pemahaman masyarakat untuk mengubah sikap dan perilaku kearah yang diharapkan. Persepsi rumah tangga terhadap strategi komunikasi P2KP dalam membangun kebiasaan makan pangan lokal melalui pendekatan komunikasi, pesan yang disampaikan, dan media yang digunakan tersaji pada Tabel 3.

Secara keseluruhan strategi komunikasi dalam membangun kebiasaan makan pangan lokal mempunyai rata-rata skor 44.83 dari total skor sebesar 84 atau hanya sebesar $53 \%$. Pada aspek pendekatan dan pesan, capaian skor menunjukkan bahwa strategi komunikasi yang dilakukan oleh P2KP sudah dirasakan tepat atau sesuai. Hanya saja strategi komunikasi melalui media dianggap kurang tepat karena skor rata-ratanya sangat kecil dibandingkan aspek pendekatan dan pesan.

Pendekatan yang dilakukan dalam mengenalkan, menyadarkan dan membiasakan konsumsi pangan lokal sudah dapat diterima dengan baik oleh masyarakat. Adanya pertemuan, diskusi, pelatihan dan demonstrasi pemanfaatan lahan pekarangan dapat diterima dan dilaksanakan dengan partisipasi yang baik dari masyarakat, khususnya bagi mereka yang menjadi anggota kelompok P2KP.

Sedangkan bagi yang tidak menjadi anggota kelompok, mereka dapat memperoleh informasi dan belajar dari rekan-rekan yang sudah menjadi anggota kelompok, karena informasi juga beredar melalui obrolan-obrolan sederhana yang terjadi di masyarakat. Selain itu, apabila informasi yang diperoleh dirasakan masih kurang, mereka dapat bertanya langsung kepada penyuluh atau fasilitator desa yang merupakan perpanjangan tangan dari BKP atau kepada orang yang dianggap lebih mengerti. Adanya lomba pengolahan pangan lokal ikut memberikan motivasi bagi masyarakat untuk menciptakan aneka masakan yang diharapkan memberikan variasi dalam penyajian sehingga dapat mengatasi rasa bosan mengkonsumsi pangan lokal.

Melalui kegaitan penyuluhan, kegiatan yang dilakukan P2KP mampu meningkatkan kemampuan masyarakat dalam memproduksi bahan pangan melalui pemanfaatan lahan 
Tabel 3. Persepsi Rumah Tangga terhadap Strategi Komunikasi yang Dilakukan oleh Badan Ketahanan Pangan (BKP)

\begin{tabular}{|l|l|l|l|l|}
\hline No. & $\begin{array}{l}\text { Aspek Persepsi } \\
\text { terhadap Strategi } \\
\text { Komunikasi }\end{array}$ & $\begin{array}{l}\text { Interval } \\
\text { Skor }\end{array}$ & $\begin{array}{l}\text { Skor rata- } \\
\text { rata }\end{array}$ & $\begin{array}{l}\text { Capaian skor } \\
\text { Pelaksanaan } \\
\text { Strakom (\%) }\end{array}$ \\
\hline 1 & Pendekatan & $0-29$ & 21.35 & 74.00 \\
\hline 2 & $\begin{array}{l}\text { Pesan yang } \\
\text { Disampaikan }\end{array}$ & $0-25$ & 17.02 & 68.00 \\
\hline 3 & Saluran/Media & $0-30$ & 6.45 & 22.00 \\
\hline \multicolumn{2}{|l|}{ Jumlah } & $\mathbf{0 - 8 4}$ & $\mathbf{4 4 . 8 3}$ & $\mathbf{5 3 . 0 0}$ \\
\hline
\end{tabular}

Sumber: Analisa data Primer $2016(\mathrm{~N}=280)$

pekarangan. Meskipun belum dapat merubah total kebiasaan makan sumber pangan lokal, sudah mampu mendorong rumah tangga untuk melakukan diversifikasi pangan lokal. Penyuluh sebagai fasilitator, selalu hadir di tengah masyarakat, memfasilitasi proses kegiatan dan mengaktifkan jalannya proses belajar melalui pertemuan rutin, pelatihan dan diskusi baik untuk perorangan ataupun kelompok. Hubungan yang terjalin antara penyuluh dengan masyarakat juga berjalan dengan baik, sehingga selalu siap sedia hadir memberikan dukungan kepada masyarakat untuk melakukan diversifikasi pangan lokal.

Pesan-pesan diversifikasi pangan lokal menarik untuk diikuti, sehingga menambah pengetahuan dan minat untuk mengubah kebiasaan makan. Meskipun pada kenyataannya belum sepenuhnya dapat mengubah kebiasaan makan masyarakat, tetapi pesan-pesan yang didapatkan mampu meningkatkan pengetahuan dan memotivasi untuk melakukan keragaman konsumsi pangan dengan sumberdaya pangan lokal. Pesan yang disampaikan mampu membangun kesadaran bahwa pangan lokal dapat diproduksi dengan cara yang sederhana, mudah, dan murah dengan memanfaatkan lahan pekarangan sebagai unit produksi pangan untuk rumah tangga.

Untuk media cetak, hanya leafleat yang dianggap mampu memberikan informasi yang lengkap dan jelas mengenai konsumsi pangan lokal karena mudah mereka peroleh dari penyuluh, puskesmas, kepala desa dan anggota kelompok P2KP yang aktif. Informasi dari leaflet biasanya lebih singkat dan jelas sehingga sangat informatif, apabila ada informasi yang membutuhkan penjelasan lebih detail biasanya mereka akan menanyakan kepada orang yang lebih mengerti. Koran/tabloid dianggap tidak memberikan informasi diversifikasi pangan karena sebagian besar responden tidak pernah mengakses media tersebut karena dibatasi oleh faktor ekonomi, karena mereka menganggap kebutuhan dasar rumah tangga dan sekolah anakanak mereka lebih penting daripada membeli media tersebut. Selain itu, waktu mereka juga sehari-hari dihabiskan untuk bekerja di kebun/ sawah dan pekerjaan domestik yang sangat menyita waktu. Informasi mengenai diversifikasi pangan dari media elektronik khususnya televisi dan radio tidak pernah dinikmati informasi mengenai konsumsi pangan lokal tidak setiap saat ditayangkan, dan jika ditayangkanpun mereka sedang menjalankan aktivitas keseharian sehingga tidak sedang menikmati media yang menyiarkannya. .

Tidak berkontribusinya media dalam penelitian ini menunjukkan bahwa strategi yang dilakukan dalam kegiatan P2KP belum mampu melibatkan semua saluran komunikasi untuk kepentingan yang sama bagi segenap anggota masyarakat. Masyarakat lebih banyak memperoleh pesan melalui hubungan atau kontak dengan orang lain dari pada menerima langsung dari media massa. Interaksi sosial menjadi kunci yang menentukan bagaimana pesan-pesan 
diversifikasi pangan lokal terdifusi dalam sistem sosial. Komunikasi antar pribadi pada umumnya lebih efektif dalam mendifusikan suatu informasi dibandingkan dengan komunikasi lewat media massa. Situasi ini dapat dijelaskan melalui teori hubungan sosial dari Malvin L De fleur, teori ini berasumsi bahwa pada dasarnya pesanpesan komunikasi massa lebih banyak diterima individu melalui komunikasi antar pribadi dibanding menerima langsung dari media massa (Depari dan MacAndrews, 2006). Banyak faktor yang berhubungan erat dengan berkembangnya komunikasi antar pribadi di pedesaan, antara lain: 1) tingkat interaksi masyarakat yang tinggi, 2) motivasi yang rendah untuk mencari informasi dari luar desanya, 3) kurangnya kemampuan masyarakat untuk memanfaatkan media massa sebagai sumber informasi 4) terbatasnya akses terhadap media massa.

Tetapi, dijelaskan kemudian bahwa sesungguhnya penyebaran informasi dalam suatu masyarakat dapat berjalan melalui dua tahap. Pertama, informasi berkembang melalui media kepada individu-individu yang relative kosmopolit dan "well informed" yang memperoleh informasi lagsung dari sumber utama biasanya individu-individu ini merupakan opinion leader atau pemuka pendapat dalam suatu sistem sosial. Kedua, informasi tersebut berkembang melalui saluran komunikasi antar pribadi kepada individu-individu yang tidak mampu mengakses informasi dari media dan mempunyai ketergantungan yang tinggi kepada orang lain akan informasi tertentu. Proses semacam ini disebut Lazarsfeld sebagai teori arus dua langkah (Littlejohn dan Foss, 2014) yang menurut De fluer sebagai teori yang berhubungan dengan teori hubungan sosial. Dalam hal ini, teori hubungan sosial menekankan pentingnya hubungan antar pribadi sebagai sumber informasi maupun sebagai penguat dari pengaruh media komunikasi.

Dengan demikian, strategi komunikasi yang dilakukan dalam kegiatan P2KP haruslah dapat menyesuaikan dengan situasi yang ada di lapangan. Ketika menggunakan media massa sebagai ujung tombak penyebaran informasi ke masyarakat, haruslah dipilih media yang benar-benar dapat diakses langsung dan bisa menyampaikan pesan diversifikasi kepada masyarakat, misalnya dengan mengotimalkan penyebaran informasi melalui leafleat yang diakui sebagai media yang mudah diakses dengan informasi yang tepat dan mudah dipahami. Penyebaran informasi melalui media massa lain seperti koran, audio, audio visual tetap diperlukan, untuk menyebarkan informasi secara masal dan juga untuk memperkaya informasi bagi "pemuka pendapat" yang lebih mampu mencari dan memanfaatkan informasi dari media.

\section{Simpulan}

Model perencanaan komunikasi kegiatan P2KP merupakan model perencanaan yang tahapan-tahapan tidak begitu berbeda dengan tahapan-tahapan pada model sebelumnya karena melalui tahapan yang umum seperti: perencanaan, persiapan, pelaksanaan, serta evaluasi dan monitoring.

Pelaksanaan kegiatan P2KP sudah memuat komponen strategis dalam komunikasi pembangunan seperti yang dijelaskan dalam $a$ guide on communication planning for communitybased development yaitu: 1) Behavior Change communication $(B C C, 2)$ Social mobilization, dan 3) Advocacy.

Strategi komunikasi yang dilakukan melalui kegiatan P2KP sudah dianggap tepat dan mampu menyampaikan pesan-pesan diversifikasi dan mengubah kebiasaan makan pangan lokal masyarakat. Khususnya pada aspek pendekatan dan pesan, capaian skor menunjukkan bahwa strategi komunikasi yang dilakukan oleh P2KP sudah dirasakan tepat atau sesuai dalam mengubah pengetahuan dan perilaku diversifikasi konsumsi pangan lokal. Hanya saja strategi komunikasi melalui media dianggap kurang tepat karena keterjangkauan masyarakat dalam mengakses informasi mengenai diversifikasi pangan melalui media massa juga sangat rendah. 
Daftar Pustaka

Cangara, H. 2000. Pengantar Ilmu Komunikasi. Jakarta: PT. Radjawali Pers.

Depari, E., dan MacAndrews, C, 2006. Peranan Komunikasi Massa dalam Pembangunan. Yogyakarta: UGM Press.

DeVito, JA. 2006. Human Communication: The Basic Course. United States of America: Pearson Education. Inc.

Effendi, O,U., 2003. Dinamika Komunikasi, Bandung: Remaja Rosdakarya

Husodo, S.Y dan Muchtadi T.R, 2004, Alternatif Solusi Permasalahan Pangan dalam Widya Karya Nasional Pangan dan Gizi VIII. Jakarta: LIPI.

Khomsan, A 2004, Peranan Pangan dan Gizi untuk Kualitas Hidup. Jakarta: Grasindo

Littlejohn. SW., dan Foss, KA., 2014, Teori Komunikasi. Theories of Human Communication, Jakarta: Salemba Humanika. dan
Singapore: Cengage Learning.

Malik, H, 2014, Melepas Perangkap Impor Pangan, Jakarta: LP3ES Mardikanto, Totok. 2009. Sistem Penyuluhan Pertanian. Surakarta: UNS Press. Middleton, J. dan Lin, Yvonne, H., 1975. Planning Communication for Family Planning. Honolulu: East west Center. East-West Communication Institute. Nasution, Z, 1998, Komunikasi Pembangunan. Pengenalan Teori dan Penerapannya, Jakarta: PT RadjaGrafindo.

Rogers, M. Evertt, 2003. Diffusion of Innovations, New York: Free Press Undang-undang Republik Indonesia No. 18 Tahun 2012 Tentang Pangan.

Versoza, C.C dan Garcia, H,R., 2009 Building CommitmenttoReform Through Strategic Communication. TheFiveKeysDecisions, Washington DC: The World Bank. 